Pediat. Res. 12: 1137-1138 (1978)

\title{
Introduction of Howland Award
}

\author{
ALEXANDER NADAS
}

Children's Hospital Medical Center, Boston, Massachusetts, USA

\section{Mr. President, Members, and Guests:}

It gives me particular pleasure, and fills me with great pride, to present the John Howland Award of the American Pediatric Society to Dr. Charles A. Janeway, scientist, world citizen, and role model par excellence for the American Academic Pediatrician.

Dr. Janeway, born in New York in 1909, comes from a distinguished medical family. His grandfather, Dr. Edward Gamaliel Janeway, was a well known internist in New York City, a clinician, but also part-time Professor of Pathology and Dean of the Bellevue Medical School, Precursor to NYU. Perhaps he is best known for certain reddish papular lesions of the palms and soles: the Janeway spots. "Numerous, small hemorrhages with slightly nodular character in the palms and soles" he wrote, and suggested that they are diagnostic of bacterial endocarditis.

Dr. Janeway's father, Dr. Theodore C. Janeway, followed in the footsteps of his own father by becoming an internist, but by pursuing an academic career, became the first full-time Professor of Medicine at the Johns Hopkins Hospital, where he occupied the Osler Chair. As I understand it, this was one of four such chairs established by the Rockefellers, in response to the Flexner Report.

Dr. Theodore Janeway, died quite young, in 1917, a victim of pneumococcus pneumonia in the wake of the beginning influenza pandemic. He contracted his illness, presumably, while evaluating for the government the health care of American Army recruits.

Our Dr. Janeway was then 8 years old, attending the Calvert School in Baltimore, a private school of still excellent reputation, best known for its correspondence courses for the children of American missionaries and diplomats all over the globe. Perhaps one sees here the beginnings of international influences, just as the utimely death of his father, while a government consultant, is in harmony with the son's devotion, in his career, to public service. Moreover, Dr. Janeway remembers how somebody at the Calvert School with an obvious sense of the crystal ball snapped his picture, as a little boy, trying to untangle a snarled rope or line. I need not elaborate on the prophetic nature of this picture of the five-year-old C.A.J. patiently attacking Gordian knots. From the Calvert School, he went to other private schools in New York as the family moved back there and, eventually, at the age of 12 , reached Boston for the first time and was enrolled in Milton Academy, from which he graduated in 1926. He received his A.B. Degree from Yale in 1930. He could not make up his mind 'til rather late in his senior year whether he should go to medical school. A friend of his father, who taught physiology at Cornell, took young Charlie under his wings and persuaded him to enter that medical school, where he took his first 2 years. He transferred to Hopkins for his third, the first clinical years, for several reasons. The first and clearly the most important reason was his marriage to Elizabeth Bradley, a Vassar graduate, who became a medical social worker at the Hopkins Hospital.

After graduating from Hopkins in 1934, the young man went Northeast for a medical internship at Boston City Hospital. The 2 years he spent there might have been among the most important ones of his career, for he thus came under the influence of the superb medical group at Harvard's Thorndike Laboratory, particularly Dr. Soma Weiss, the charismatic Hungarian, later Professor of Medicine at the Peter Bent Brigham Hospital, 'til his untimely death in the early Forties. After a junior assistant residency at Hopkins, note again, in Medicine, the Janeways came back to Boston, this time to stay, in 1937. After a brief flirtation with the idea of entering practice in one of the prestigious medical firms in Boston, he decided, under the influence of Dr. Soma Weiss and others, to join Dr. Hans Zinsser's laboratory at the Harvard Medical School. He stayed there for 2 years, first as a research fellow, then as an Instructor in Bacteriology and Immunology. Hans Zinsser, whose autobiography, As I Remember Him, and medicohistorical volume, Rats, Lice and History, are classics, was the second major influence on the young Charles Janeway. Again, this was a powerful laboratory, with a very stimulating scientific ambiance. Imagine having lunch almost daily with Hans Zinsser and John Enders, among others. In 1939, he became Assistant, then Instructor and Associate in Medicine at the Peter Bent Brigham Hospital and was clearly one of the handful of young men Soma Weiss wanted for a new Brigham staff, in which Dr. Janeway would be responsible for infectious diseases.

So, there he was, 30 years old, in 1939, launched in Internal Medicine, with a growing interest in infectious diseases, when he discovered that there were more such problems at the Children's Hospital across the bridge than at his end of it at the Brigham. Moreover, the Children's was becoming dependent on him in that area. I remember, as a Children's Hospital house officer, his Grand Rounds in 1942 on typhoid in children compared with that in adults. As a consequence of his interest in infectious diseases of children, and his involvement at the Children's Hospital, he allowed himself to be appointed Assistant Professor of Pediatrics in 1942; clearly, I believe, being groomed by the wise men of the faculty to become Physician-in-Chief, successor to Dr. Kenneth Blackfan, after a very distinguished, brief interregnum by Dr. Richard M. Smith. In 1946, he became Physician-in-Chief at the Children's Hospital, and Thomas Morgan Rotch Professor of Pediatrics. Mind you, much of his pediatric training had still to be on-the-job education: he did not pass his Pediatric Boards until after he became Head of the Department. I would propose two conclusions from this story. A) Smoke filled committee rooms inhabited by a few knowledgeable people do have their useful roles, and community representatives are not indispensable in arriving at brilliant appointments. B) The American system of open doors, or perhaps more importantly, open back doors, is a very useful means of entrance to center stage.

While all this was going on at the Children's Hospital storm clouds were gathering across the Atlantic. In early 1940's, Dr. Walter Cannon, Professor of Physiology at the Harvard Medical School and Chairman of the Committee on Shock of the National Research Council, persuaded Dr. Edwin Cohn, Head of the University Laboratory of Physical Chemistry at the Harvard Medical School, to initiate a program of using bovine albumin for the armed forces to combat shock. Knowing all the immunologic difficulties that Dr. Owen Wangensteen of Minnesota had encountered with bovine albumin in a very few postoperative patients, Dr. Cohn turned to his friends at the Medical School to 
recommend somebody with both medical and immunologic knowhow for the fractionation program of human plasma, since an animal product might prove to be impractical. Thus, Dr. E. J. Cohn became the third major influence on Dr. Janeway in the early years.

For the next 30 years, his career is a matter of history. Perusal of his bibliography, discussions of his research with colleagues, particularly, Dr. Fred Rosen, allows an attempt to summarize with the broadest strokes his scientific accomplishments from the highlights of the four distinct, but closely interlocking research areas that blend into the tapestry of his scientific oeuvre.

Bacteriology and chemotherapy, Dr. Janeway's main interest at the outset, appear in a number of contributions on the mode of action and indications for use of sulfonamides. He published on Salmonella infections, streptococci, and lymphocitic choriomeningitis.

The next cluster of his significant contributions covers the use of blood fractions, particularly albumin, first bovine, then human, in military medicine for the treatment of hypovolemic shock. This brought him deeply into the entire blood procurement program the Red Cross, and the National Research Council. The contributions of citizen Janeway in this area were almost as great as those of scientist Janeway.

The third area, and you may perceive the rich colors of the tapestry developing through interlocking patterns, is in renal disease. An important result of this life-long interest was the experimental production with Hawn of glomerulonephritis in rabbits by injection of purified foreign serum protein. This permitted the simultaneous study of the behavior of the foreign protein, its antibody and complement, and their correlation with the sequence of tissue changes. Other immunochemical and turnover studies of plasma proteins in patients with the nephrotic syndrome, done by David Gitlin, led eventually to the clear demonstration that its hyperlipidemia is a direct consequence of its hypoalbuminemia. It was the group of young investigators under Dr. Janeway who first established, in animal models, the connection between membranoproliferative glomerulonephritis and complement.

Probably the most significant, and surely the best known investigative thrust of his whole research career, is that relating to the immunoglobulins. While Dr. Janeway was deeply involved in the human albumin project in the 1940's, he had put away, in deep freeze, with characteristic foresight, the serum of interesting patients with very severe infections to be looked at later. So, after the war, out came the test tubes and the historical and classical descriptions of $\mathrm{A}$, hypo, and dysgamma globulinemia, and the multiple serum protein deficiencies, described by Gitlin and Hitzig, associated with both the acquired and congenital forms of Agamma globulinemia followed.

These then are the four scientific areas distinguishable as separate strands making up the Gobelin of his research accomplishments. As though these were not enough for any one man, we must touch, much too briefly, on his activities in world Pediatrics where his influence was strongly felt. I believe his relationship with the pediatricians and children of the Indian subcontinent are still very close. He spent a sabbatical leave there in 1956, then returned in 1970 for a part of a second sabbatical, the other part of which was spent in Korea. His hosts in both places were pupils from Boston, and he made new friends who later visited with him back at the Children's Hospital in Boston. Working our way back west, one has to mention his guiding spirit in the early years of the Nemazee Hospital in Shiraz, Iran. Then of course he had an influence on the child health policies of Turkey through his close relationship with Dr. Ihsan Dogramaci, friend and pupil and Minister of Health, who succeeded Dr. Janeway as Head of the International Pediatric Association. Working our way further west, one cannot omit his membership in the Board of the International Children's Center, an organization engaged over 25 years in teaching child health to physicians in developing countries. Since 1973, his major international project has been the Harvard Project at Yaounde in the Cameroons, a multiprofessional undertaking, aiming, through training of native health personnel, at meeting the specific health problems of Africa. Finally, coming back to this Continent, one finds the Dr. Charles A. Janeway Children's Center in St. John's Newfoundland.

What may be the most significant of Dr. Janeway's professional contributions, his role as a teacher, a Medical School Professor, is the hardest to compress into a final paragraph. It would take far too long to enumerate the tangible accomplishments alone: how many department chairmen trained, how many divisions established, and how many others nurtured until they could break off as independent departments. A magnificent track record well known to most of you in this room. Rather than attempting any such list, I would prefer to try listing the human attributes that Charlie Janeway taught, always by precept, never by preaching, throughout his career, to all those he came in contact with. Whoever he touched did carry away from the encounter some, if not all, of his constant characteristics. He is always considerate, and always trying to see the other side of the question. His objectivity, sometimes frightening, is always inspirational. $\mathrm{He}$ is simple, unpretentious, even austere. His patience is always exemplary. In always assuming that everybody else always acted from the best of motives, he shows an idealism I like to think of as very American.

Dr. Janeway retired as Thomas Morgan Rotch Professor from the Harvard Medical School, after 29 years of service, in 1975. He now enjoys his Emeritus status by coming into the Hospital a bit later in the morning, and going home a little earlier in the afternoon. He also carries now only one briefcase, instead of the usual two. He visits on the ward, teaches medical students and house staff, and travels widely. Weekends with his family are more leisurely these days and he reads the New York Times on the beach rather than correcting manuscripts. All of this is a change of pace, not of direction.

As Dr. Clement Smith said, we are happy to honor him, but we should be happier still, if we could find words to thank him. 